\title{
Students' Attitude towards Teachers' Use Of Code-Switching and Its Impact on Learning English
}

\author{
Ahmer Rauf ${ }^{1}$ \\ ${ }^{1}$ Govt. Postgraduate College Burewala, Burewala, Pakistan \\ Correspondence: Ahmer Rauf, Govt. Postgraduate College Burewala, Burewala, Pakistan. E-mail: \\ ahmer.rauf@yahoo.com
}

Received: February 21, 2017 Accepted: August 11, 2017 Online Published: October 25, 2017

doi:10.5539/ijel.v8n1p212 URL: https://doi.org/10.5539/ijel.v8n1p212

\begin{abstract}
The ability of using two languages simultaneously with native like proficiency is called bilingualism. The present study explores the attitude of the students towards the use of code-switching, the relationship between code-switching and its effects on students' learning and the impact of Urdu-English code-switching on students' proficiency in target language. In Pakistan, no proper attention is ever paid to the different aspects of bilingual code-switching in classroom and it is the need of the hour to develop an in-depth understanding of bilingual code-switching in particular Pakistani context and to get insight into the importance of different usages and functions of bilingual code-switching in Pakistani ELT classrooms. The researcher has gone for the quantitative approach to achieve the objectives of this study as it renders the research to produce calculated and generalizable results. So, a questionnaire comprising of 35 questionnaire items on Likert Scale was designed to collect data from 400 male and female intermediate ESL learners and the collected data were analyzed through SPSS version XX. The study provides identifying motivational challenges in the use of bilingual (English-Urdu) code-switching and in taking a more realistic perspective about the ELL (English Language Learning) situation in the country.
\end{abstract}

Keywords: bilingualism, code-switching, code-mixing, ELT, Pakistani classrooms

\section{Introduction}

The ability of using two languages simultaneously with native like proficiency is called bilingualism. It may be a range of minimal language proficiency in two languages to higher level of proficiency that confirms the speaker to speak with native like proficiency. A speaker may be bilingual due to having learning and using two different languages simultaneously or he may be a bilingual by getting an L2 after his L1. Bilingualism conveys several meanings to different people. Bilingualism encompasses a range of proficiencies and contexts. In terms of competence, a bilingual speaker might have an advanced level of proficiency in two languages or might be less proficient in one language and more proficient in second language. The term "bilingual" is dependent on: the particular context; language use proficiency and the purpose of communication. Every language is a code. The use of this bilingual-switching and bilingual -mixing is the common trait of any human society. It is common all over the world. It can be defined as code-switching is the mixing of words, phrases and sentences from two distinct grammatical (sub) systems across sentence boundaries within the same speech event... code-mixing is the embedding of various linguistic units such as affixes (bound morphemes), words (unbound morphemes), phrases and clauses from a co-operative activity where the participants, in order to infer what is intended, must reconcile what they hear with what they understand.

The ability of using two languages simultaneously with native like proficiency is called bilingualism. It may be a range of minimal language proficiency in two languages to higher level of proficiency that confirms the speaker to speak with native like proficiency. The mixing of words, phrases or sentences from the different grammatical systems or languages for the same utterance or the same speech event is known as code switching. It also means the process of embedding different morphemes, words and sentences so that the participants may reconcile what they hear and what they perceive. The purpose behind code-switching is the inference of what is intended to be communicated in the speech event.

The study of bilingualism and its effects on students' language development seems remains a fascinating subject with many implications which the present researcher intends to identify. The present study may not yet expose 
all the complicated sides of bilingual code-switching in ELT classrooms but it will certainly serve as an important input in understanding the field better. Code-switching is a wide horizon phenomenon in bilingual field. Most of the researchers are particularly concerned with the discourse functions and social and sociological aspects and social interpretations of code switching which naturally indicates that research in bilingual code switching is usually the sociolinguistic aspect of the language. According to Gulzar (2013), teachers go for code-switching in the English language classroom in the context of Pakistan because English is taught as a compulsory subject here and this language is the medium of instruction even at primary level.

\subsection{Objectives of Study}

The researcher has conducted this study to achieve some objective and these objectives have been given as follows;

- $\quad$ The measure the attitude of the students towards the use of code-switching.

- $\quad$ To find out the relationship between code-switching and its effects on students' learning.

- $\quad$ To measure the impact of Urdu-English code-switching on students' proficiency in target language.

\subsection{Research Questions of the Study}

This study has raised certain research questions and these questions have been given as follows;

- What is the attitude of the students towards the use of code-switching?

- What is the relationship between code-switching and its effects on students' learning?

- What is the impact of Urdu-English code-switching on students' proficiency in target language?

\section{Literature Review}

The ability of using two languages simultaneously with native like proficiency is called bilingualism. It may be a range of minimal language proficiency in two languages to higher level of proficiency that confirms the speaker to speak with native like proficiency. A speaker may be bilingual due to having learning and using two different languages simultaneously or he may be a bilingual by getting an L2 after hisL1. Bilingualism conveys several meanings to different people. Bilingualism encompasses a range of proficiencies and contexts. In terms of competence, a bilingual speaker might have an advanced level of proficiency in two languages or might be less proficient in one language and more proficient in second language. The term "bilingual" is dependent on: the particular context; language use proficiency and the purpose of communication. Every language is a code. The use of this bilingual-switching and bilingual -mixing is the common trait of any human society.

Code-switching is a very common phenomenon in the conversation of bilinguals/multilingual. Urdu enjoys the status of national and official language of Pakistan. Whereas English is co-official language in Pakistan (cf. Akram \& Mahmood, 2007). According to Baumgardner (1993), in wake of new social and contextual use people get use of words from Pakistani local vernaculars which refer back to Pakistani culture and society.

There are a lot of terms refer to code switching including "code mixing; tag-switching and code-changing, metaphorical and situational code-switching".

Situational code-switching happens when due to a difference in setting, conversational participants or topic, a speaker selects to speak in a different language than s/he was originally speaking (Wardhaugh, 2006). For example, a group of people of Japanese-English bilinguals busy in conversation in Japanese may switch to English when they see that a monolingual English speaker comes and joins their conversation. This concept may also apply to the shifting between different registers within a language e.g., a teenager boy may speak English of Standard American accent when conversing to a teacher, but switch to a lower level register of slang English when his friends approach.

Davies \& Bentahila (1994) try to justify the use of code-switching in situational switching as they claim that speakers use one language in one situation while another language in another situation. For instance, a speaker might use one language at home while another language at workplace. These researchers also claim that sometimes different domains can intersect and a speaker speaks different languages in different settings. In this respect, Davies \& Bentahila (1994) maintain that a linguistic and psychological ability is the prime requisite for the correct analysis of the language used in different situations, choice of a specific style or code and the comprehension of that choice in a befitting manner.

Conversational switching is another kind of code-switching recommended by Gumperz (1976). Here, a speaker does code-switches even in a single utterance and does it even for many times without considering the equal proportion of the mixed codes. In such cases, a speaker utters one sentence in one variety while another in a 
quite different variety. Hudson (1980) also defines such speech events as conversational switching.

The intra-sentential Code Switching is the switching at the clause, phrase and word level if no morphophonological adaptation happens. It is the most complicated type of code switching, requires as it does that the speaker of the language be able to command two linguistic systems at a time. e.g.: Abelardotiene los movie tickets. (Abelarda has the tickets of movie). (Hammink, 2000, p. 3) Poplack also studied that idiomatic expressions are mostly considered to represent like bound morphemes, a few number of switches in idiomatic expressions took place in the speech of the respondents.

Don (2003) came to know that Code switching was most of the times made up of inter-sentential Code Switching. He researched about dialect of language Code Switching (especially Standard Malay/ Kelantanese Malay Code Switching). The results of the study revealed that the most of his subjects' code switched intersententially. Code switching in a single talk is a common important activity of subjects. A lot of the Code Switching is involved in a whole utterance while there were very few happenings of small constituents in utterances.

Code Switching is done differently when it takes place in different settings. Macias \& Quintero (1992) examined that children are capable to speak both the languages in the classroom. The main purpose of their research was to explain different types of Code Switching in the process of learning in a classroom setting with bilingual children and their parents. The results represented that the children spoke both languages without any hurdle in oral discourse with their teacher and their parents. They also communicated in an effective way through the use of English and Spanish. Dandee's (2003) research reinforces Macias \& Quintero (1992) results. She examined Code Switching between Thai and English and paid attention on study-days (inside the classroom) and also on non-study-days (outside the classroom). She examined the relationship between Code Switching and social factors: location, interlocutor, gender, subject matter, and educational background. The findings revealed that Code Switching happened in the classroom more than out of the classroom.

Borrowing referred to only lexicon and commonly one word item is taken from another language in a bilingual speech (kovacs, 2001). According to Jumperz (1982), borrowing can be defined to introduce single word item and idiomatic phrases taken from one language to other language; moreover, these words are combined into the grammatical systems of the borrowing language. On the other hand, code switching is a juxtaposition of two different varieties which operate under the two distinct grammatical systems (Gumperz, 1982). A borrowed item can be regarded as a morphologically, syntactically and phonologically, integrated item (Poplack, 1980).

Zentella (1997) investigated that speakers would commonly begin in the language they themselves were feeling most comfortable in, but then they would switch to the language of some newcomer that has joined the conversation. Switches also happened to clarify a statement, to stress something that had already been said to express politeness or even to show one's powers in both languages.

Brice, Mastin, \& Perkins (1997) defined that in all of the examples of code switching, none of them were grammatically incorrect and the examples followed rules. They came to the conclusion that code switching is not a symbol of language confusion. In English, as Second Language classroom where only English was employed for instruction, the same group of researchers came to know that $17.41 \%$ of all utterances employed code mixing, code switching, or the use of mother tongue (Brice, Mastin, \& Perkins (1997). According to Tarone \& Swain (1995), interested students seem to have a powerful preference for using their first language in the classroom, especially when they are talking with one another. Furthermore, there seems to be more use of the first language in the levels of upper grade than lower grade levels (Tarone \& Swain, 1995).

Brice \& Roseberry-McKibbin (2001) explained educators the need to carry on a flexible environment, which increases accepting answers in either mother tongue or foreign language because students are reinforced and rewarded for their participation. Under many classrooms contexts it is significant to prompt students to carry on communicating and sometimes this means to use whatever language can be meaningful at that time. When bilingual student feels comfortable in the classroom, he will code switch more frequently than when he is in a classroom where they feel their language as being not important or inadequate.

Research in the ESL classroom has not been that of wide range although there has been that type of research since the 1970's (Martin-Jones, 1995). Some of the researchers do not even take code switching in foreign language classrooms as a proper code switching (Winford, 2003, p. 108) but don't take it as "incompetence code switching". However, on the same level Winford (2003) accepts that advanced level learners utilize code switching in the same way like that of competent bilinguals.

Söderberg Arnfast \& Jørgensen (2003) investigated students when trying to perceive code switching. They chose 
two groups as their informants who were learning Danish for the first time: American English exchanges students who were learning in a one of Danish high school and first year students of Polish learning Danish in Poland. The material for study comprised of interviews which were being recorded and transcribed and the informants were not completely observed otherwise.

In Finland, code switching has never been studied widely in the classrooms. Myyryläinen \& Pietikäinen (1988) investigated teachers' hypothesis about the use of the L1 and the second language in L2 classrooms and the teachers' causes for the choice of language use. They employed a questionnaire and then recorded and then transcribed lessons data. However, their emphasis was not on code switching which takes place in the classroom. They wanted to investigate how much the use of foreign language there are in the target language classroom.

\section{Research Methodology}

The study seeks to explore the students' attitude towards the use of bilingual code switching in English classroom. For this study, a quantitative approach has been adopted to measure the relationships and interactions between sets of data using statistical analysis that provides important generalizable results. A sample is considered to be a subset of population. Sampling is supposed to be an important part of any research project. Four hundred participants (male \& female aged between 17-21 years) were selected randomly for this study. The following table shows the strength of the participants with their institutions.

\subsection{Research Tools}

In order to get data from a larger group of participants, the questionnaire is considered a very authentic and valid tool as it gives equal opportunities to the participants to respond the statements because the respondents find it quite easy and very appropriate to respond to the questionnaire rather than any voice recording. The questionnaire comprising 35 items (on five point Likert Scale) was designed in which the students were asked to give their attitude towards their use of bilingualism in language classrooms. The reliability of the questionnaire was calculated by SPSS version XX and was computed as .705. Learners' previous exam score was taken as the achievement test to check the impact of bilingual code-switching on their English learning. The previous exam score was taken as there was no confusion of the reliability and validity of the test. It was convenient for the researcher to take their previous exam score in English.

\section{Results and Discussion}

After piloting the questionnaire was translated into Urdu and the data was collected from a larger sample of 400 participants, from the above discussed institutions. The participants who took part in the piloting were not included in the main sample of the study. The data collection process took almost an hour in every institution. The participants were facilitated in data collection as the research himself collected the data. The data was analyzed by means of the SPSS (XX). The following table indicates the result of correlation between students' attitudes' towards teachers' use of code-switching and their previous exam score.

Table 1. Correlation of questionnaire and English score

\begin{tabular}{|c|c|c|c|}
\hline \multicolumn{4}{|c|}{ Correlation of Questionnaire and English Score } \\
\hline & & $\begin{array}{c}\text { Total Score } \\
\text { Questionnaire }\end{array}$ & $\begin{array}{c}\text { Score in } \\
\text { English in } \\
\text { the Previous } \\
\text { Examination }\end{array}$ \\
\hline \multirow{3}{*}{$\begin{array}{l}\text { Total Score } \\
\text { Questionnaire }\end{array}$} & $\begin{array}{l}\text { Pearson } \\
\text { Correlation }\end{array}$ & 1 & .086 \\
\hline & Sig. (2-tailed) & & .089 \\
\hline & $\mathrm{N}$ & 394 & 394 \\
\hline \multirow{3}{*}{$\begin{array}{l}\text { Score in English in the } \\
\text { Previous Examination }\end{array}$} & $\begin{array}{l}\text { Pearson } \\
\text { Correlation }\end{array}$ & .086 & 1 \\
\hline & Sig. (2-tailed) & .089 & \\
\hline & $\mathrm{N}$ & 394 & 394 \\
\hline
\end{tabular}


The above table shows the correlation result of the questionnaire with the participants' score in English exam. The result shows that $p$ value is $>0.05$ level which indicates that there is statistically no significant relationship between the mean score of the questionnaire and the English score of the students. Hence the null hypothesis "there is no relationship between teachers' use of code-switching and students' achievement" is accepted.

Table 2. T-test between gender and questionnaire score

\begin{tabular}{lcccccc} 
& \multicolumn{7}{c}{ Male $(\mathrm{N}=203)$} & \multicolumn{2}{c}{ Female $(\mathrm{N}=191)$} & T-test & Sig.2-tailed \\
\cline { 2 - 7 } Variables & M & SD & M & SD & T & P \\
\hline & & & & & & \\
Quest. Score & 148.13 & 7.876 & 147.39 & 5.409 & .902 & $p>0.05$ \\
\hline
\end{tabular}

The result of t-test shows that the mean score of male students was 148.13 and those of females mean score was 147.39 the value of $t$ was calculated as .902 and the $p$ value was calculated as $p>0.05$. This shows that statistically there is no significant difference between gender and mean score of the questionnaire i.e., gender does not affect the questionnaire score of the student. Hence the null hypothesis "male students have more positive attitude toward the use of code-switching than female students" is rejected

Table 3. T-test between gender and English score

\begin{tabular}{lcccccc} 
& \multicolumn{7}{c}{ Male $(\mathrm{N}=203)$} & \multicolumn{2}{c}{ Female $(\mathrm{N}=191)$} & T-test & Sig.2-tailed \\
\cline { 2 - 7 } Variables & M & SD & M & SD & T & P \\
\hline & & & & & & \\
English Score & 58.71 & 10.800 & 58.53 & 14.053 & .143 & $p>0.05$ \\
\hline
\end{tabular}

The result of t-test shows that the mean score of male students was 58.71 and those of females mean score was 58.53 the value of $t$ was calculated as .143 and the $p$ value was calculated as $p>0.05$. This shows that statistically there is no significant difference between gender and achievement i.e., gender does not affect the achievement of the student.

The study has found out that bilingual code switching is in vogue among the students and the teachers. The students most of the time use it from English to Urdu whereas the teachers use it from Urdu to English. The findings of the study are seconded by those of Davies' \& Bentahila's (1994) who studied why people switch languages in terms of situational switching. They find that there may be an amalgamation between the boundaries of each language used so that in different setting the speaker will make use of several different languages. The students like the use of bilingual code switching, both from English to Urdu and from Urdu to English. The teacher makes sure that in this use of code switching every student understands what the teacher wants to convey to them.

It is also interesting to note that when moving from classroom activity to another is an effective method to differentiate several classroom activities. However, sometimes there appear such situations when the teacher's use of ode switching is not planned but quite accidental or by the students switching to Urdu causes the teacher to switch to Urdu also. The findings of the present study are also similar to Bloom and Gumperz, (1972) who found that the subjects of their study used both languages irrespective of their official matters. The students use the target language when it is demanded by the activity in the classroom or to study the textbook, but Urdu for other than classroom activities and for unofficial interactions.

The findings of the study also relate to Bosnar-Valkovic's (2015) study on Code-switching in third language teaching of German. This study strived to identify the pay-offs and the functions of code-switching exercised by the teachers and also to unearth the reasons behind this phenomenon. It also brings to light the multifaceted benefits which are rendered by code-switching in the particular context of foreign language learning and the teacher-learner interaction for the successful communication in the English language classroom. 
This study clearly indicates that the participants of the study have very positive attitude towards code switching as it adds to their better learning, comprehension, and understanding of the lesson. This study supports Portelli (2015) who conducted a research in Malta to find out the attitudes of Maltese people towards code switching.

The results and findings of the study show that use of bilingual code switching reduces the learning difficulties of the participants. The study relates to Stylianou (2015) who focuses various aspects of code-switching which are related to significance of code-switching in the ESL/EFL learners' classroom, difficulties in the use of code-switching by a teacher because of classroom environment, problems faced by the ESL/EFL learners in understanding the speech event carried out through code-switching, effectiveness of the native teacher for the successful communication in the language class and the role of the individual factors in the use of code-switching in the English language classroom.

Urdu and English go side by side in English classes in Pakistan at intermediate level; both languages seem to have their own functions in the language classroom although some of the functions overlap in both (Urdu and English) of these languages.

\section{Limitations of Study}

The study certainly has some limitations. As the purpose of the study was to find the students' attitude towards the use of bilingual code switching the data provide any examples of code switching. The sample of the data was also small; the results cannot be generalized to apply all English classrooms. The study has been conducted only in the Pakistan and the study has focused on intermediate level only; if the data had been different the results could have been different as well.

\section{Recommendations of study}

1) It is argued in favor of the study that the research shows that the use of bilingual code switching assists in the teaching and learning process.

2) Further research is needed to find out the possible factors in influencing learners' use of bilingual code switching.

3) Research is needed to find correlation between learning target language and use of bilingual code switching.

\section{Conclusion}

The findings of the study clearly indicate that the use of bilingual code switching is worth studying in English classrooms in Pakistan. The use of code switching is usually employed in classrooms for a number of causes and reasons, these functions may be social, these may be discourse or pedagogical. It has also been found out that code switching is not an irritating or boring phenomenon. It is not a forbidden practice in English classrooms. Bilingualism has very important and lively role to play in communicating ideas and meanings in the language classroom. It integrates all the skills and course contents at intermediate level. The study also shows that use of Urdu facilitates learning of the participants. As code switching has not been studied in English classrooms particularly in Pakistan, the present study gives a new knowledge on the use of bilingual code switching in English classrooms. The findings indicate that code switching is interesting and meaningful phenomenon which is strategically used the use of bilingual code switching enhances the motivation of students in learning English. Code switching is an easy mode of expression.

\section{References}

Akram, M., \& Ghani, M. (2012). Motivation in learning English at intermediate level in Pakistan. INTJR, 1(3), September 2012.

Akram, M., \& Mahmood, A. (2007). The status and teaching of English in Pakistan. Language in India, 7(12).

Baumgardner, R. J. (1993). The English Language in Pakistan. Oxford: Oxford University Press Karachi.

Blom \& Gumperz, J. (1972). Directions in Sociolingiustics. San Francisco: Holt, Rinehart and Winston, Inc.

Bosnar-Valkovic, B. (2015). Code-switching in third language teaching of German. International conference on Bilingualism-Malta 2015, University of Malta, Valletta Campus.

Brice, A., \& Roseberry-McKibbin, C. (2001). Choice of languages in instruction: One language or two? Teaching Exceptional Children, 33(4), 10-16. https://doi.org/10.1177/004005990103300402

Brice, A., Mastin, M., \& Perkins, C. (1997). English, Spanish, and code switching in the ESL classroom: An ethnographic study. Journal of Children's Communication Development, 19(2), 11-20. https://doi.org/10.1177/152574019801900202 
Dandee, P. (2003). Code Switching between Thai and English in Students at International College of Mahidol University. Master Dissertation, Mahidol University in Bangkok.

Davies, E. E., \& Bentahila, A. (1994). Patterns of code-switching and patterns of language contact. Lingua, 96, 79-93. Morocco: Sidi Mohamed Ben Abdellah University.

Don, Z. M. (2003). Language-dialect CS: Kelantanese in a multilingual context. Multilingual. Kuala Lumpur: Walter de Gruyter.

Gulzar \& Al-Asmari. (2013). Code Switching: Awareness amongst teachers and students in Saudi universities EFL classrooms. Higher Education of Social Science, 6(2), 1-13.

Gulzar, A. (2010). Code-switching: Awareness about its utility in bilingual classrooms. Bulletin of Education and Research, 32(2), 23-44.

Gumperz, J. (1976). Discourse strategies. Cambridge: Cambridge University Press.

Gumperz, J. (1982). Language and Social Identity. Cambridge: Cambridge University Press.

Hammink, J. E. (2000). A Comparision of the Code Switching Behavior and Knowledge of Adults and Children. Retrieved from http//hamminkj.tripod.com/babel/CS_paper.htm

Kovács, M. (2001). Code-switching and language shift in Australian Finnish in comparison with Australian Hungarian. Åbo: ÅboAkademi University Press.

Macias, A. H., \& Quintero, E. (1992). Code-Switching, Bilingualism, and Biliteracy: A Case Study. Bilingual Research Journal, $16(3 \& 4)$, Summer/Fall.

Martin, J. M. (1995). Code Switching in the Classroom: Two Decades of Research (pp. 90-111). In L. Milroy, \& P. Muysken (Eds.).

Myyryläinen, K., \&Mirja, P. (1988). Teacher Input and the Use of the Mother Tongue in the Foreign Language Classroom. Unprinted ProGradu Thesis. University of Jyväskylä.

Poplack, S. (1980). Sometimes I'll Start a Sentence in Spanish Y TERMINO ESPANOL: Toward a Typology of Code-switching. Linguistics, 18(7/8), 581-618. https://doi.org/10.1515/ling.1980.18.7-8.581

Portelli, M. (2015). Attitudes towards Code Switching in Malta: a Sociolinguistic Study. International conference on Bilingualism-Malta 2015, University of Malta, Valletta Campus.

Rabbani et al. (2012). Gender Difference in Code-Switching and Code-mixing in Text Messages of Undergraduate Students. Retrieved from www.languageinindia.com

Söderberg, A. J., \& Normann, J. J. (2003). Code-switching as a Communication, Learning, and Social Negotiation Strategy in Firstyear Learners of Danish. International Journal of Applied Linguistics, 13(1), 23-53. https://doi.org/10.1111/1473-4192.00036

Strupeck, R. A. (2006). Code Switching in an ESL Classroom: A Case Study with four Hmong Middle School Students. Unpublished M.A. in ESL Capstone. Retrieved from $\mathrm{http} / / /$ www.hamline.edu/education/academics/resources_advising/pdf/capstone_strupeck.pdf

Stylianou, N. (2015). Code Switching in an EFL Environment. International conference on Bilingualism-Malta 2015, University of Malta, Valletta Campus. https://doi.org/10.13189/1ls.2015.030601

Wardhaugh, R. (1992). An Introduction to Sociolinguistics. USA: B. Blackwell.

Winford, D. (2003). An Introduction to Contact Linguistics. Malden: Blackwell Publishing.

\section{Copyrights}

Copyright for this article is retained by the author(s), with first publication rights granted to the journal.

This is an open-access article distributed under the terms and conditions of the Creative Commons Attribution license (http://creativecommons.org/licenses/by/4.0/). 